\title{
PEMBATALAN MEREK TERDAFTAR DIHUBUNGKAN DENGAN ASAS KEPASTIAN HUKUM BAGI PEMILIK MEREK
}

\author{
Asep Suryadi \\ Alumni Doktor Ilmu Hukum Pascasarjana Unisba \\ (Lektor Kepala Sekolah Tinggi Hukum Bandung) \\ E-mail : fa_suryadi_law_firm@yahoo.com
}

\begin{abstract}
Abstrak- Pendaftaran Merek sangat penting, mengingat hak atas merek sebagai hak eksklusif bagi pemilik merek timbul dari adanya pendaftaran. Dalam praktik, ternyata merek yang sudah didaftarkan, dapat dibatalkan melalui gugatan ke pengadilan. Tujuan penelitian untuk memahami pengaturan pembatalan merek terdaftar dalam sistem pendaftaran konstitutif, untuk menjelaskan implementasi pembatalan merek terdaftar dalam sistem pendaftaran konstitutif dihubungkan dengan asas kepastian hukum. Penelitian ini menggunakan metode pendekatan yuridis normatif, penelitian ini bersifat deskriptif analitis, sumber data yang digunakan adalah data sekunder yang terdiri dari bahan hukum primer, sekunder, dan tersier yang diperoleh dari studi kepustakaan dan dianalisis dengan metode normatif kualitatif. Hasil penelitian menunjukkan bahwa pengaturan pembatalan merek terdaftar dalam sistem pendaftaran konstitutif khususnya di Indonesia, sudah diatur dalam Undang-Undang Nomor 20 Tahun 2016 tentang Merek dan Indikasi Geografis, pada Pasal 76 sampai dengan Pasal 79. Implementasi pembatalan merek terdaftar dalam sistem pendaftaran konstitutif sudah sesuai dengan asas kepastian hukum.
\end{abstract}

\section{Kata Kunci : Pendaftaran Merek, Hak Merek, Asas Kepastian Hukum}

Abstract- Trademark registration is very important, bearing in mind that the rights to the trademark as exclusive rights for the trademark owner arise from registration. In practice, it turns out that trademarks that have been registered can be canceled through a lawsuit to the court. This study aimed at understanding the regulation of the cancellation of registered marks in the constitutive registration system, explaining the implementation of the cancellation of registered marks in the constitutive registration system related to the principle of legal certainty. This study used normative juridical approach with analytical descriptive method. The source of the data used secondary data consisting of primary, secondary, and tertiary legal materials obtained from literature study and analyzed with qualitative normative method. The result shows that the regulation on the cancellation of registered trademarks in the constitutive registration system, especially in Indonesia, has been regulated in Law Number 20 Year 2016 concerning Geographical Marks and Indications in Article 76 through Article 79. The implementation of the cancellation of registered marks in the constitutive registration system is following the principle of legal certainty.

Keywords: Trademark Registration, Trademark Rights, Legal Certainty Principle 


\section{A. PENDAHULUAN}

\section{Latar Belakang Masalah}

Hak Kekayaan Intelektual (selanjutnya disingkat HKI) adalah terjemahan resmi dari Intellectual Property Rights. Berdasarkan substansinya, HKI berhubungan erat dengan benda tidak berwujud serta melindungi karya intelektual yang lahir dari cipta, rasa dan karsa manusia 1. Pengertian dari HKI adalah hak yang berasal dari hasil kegiatan kreatif suatu kemampuan daya pikir manusia yang diekspresikan kepada khalayak umum dalam berbagai bentuknya, yang memiliki manfaat serta berguna dalam menunjang kehidupan manusia, dan bernilai ekonomis ${ }^{2}$.

HKI pada umumnya berhubungan dengan perlindungan penerapan ide dan informasi yang memiliki nilai komersial. HKI adalah kekayaan pribadi yang dapat dimiliki dan diperlakukan sama dengan bentuk-

\footnotetext{
1 Tomi Suryo Utomo, Hak kekayaan intelektual (HKI) di Era GlobalSebuah Kajian Kontemporer, Graha Ilmu, Yogyakarta, 2010, Hlm. 1

2 Hery Firmansyah, Perlindungan Hukum Terhadap Merek, Pustaka Yustisia, Jakarta, 2011, HIm. 15
}

bentuk kekayaan lainnya ${ }^{3}$. Pada intinya HKI adalah Hak untuk menikmati secara ekonomis hasil dari suatu kreatifitas intelektual ${ }^{4}$.

Sama halnya dengan hak cipta dan paten serta hak kekayaan intelektual lainnya, merek merupakan bagian dari HKI. Merek adalah sesuatu yang ditempelkan atau dilekatkan pada satu produk, tetapi ia bukan produk itu sendiri. Seringkali setelah barang dibeli, mereknya tak dapat dinikmati oleh pembeli. Merek mungkin hanya menimbulkan kepuasan bagi pembeli, dan benda materilnya yang dapat dinikmati. Merek itu sendiri ternyata hanya benda immateril yang tak dapat memberikan apa pun secara fisik. Inilah yang membuktikan bahwa merek itu merupakan hak kekayaan immaterial ${ }^{5}$. Agar supaya suatu merek dapat

3 Tim Lindsey, Eddy Damian, Simon Butt, Tomi Suryo Utomo, Hak Kekayaan Intelektual SuatuPengantar, Alumni, Bandung, 2003, Hlm. 3

${ }^{4}$ Maryana, Gozali Abdillah, Cecep Samsul, Hak Kekayaan Intelektual Menurut Hukum Islam dan Hukum Adat, , Jurnal Scientica, vol I No. 2, 2013, Hlm. 59

${ }^{5}$ OK. Saidin, Aspek Hukum Hak Kekayaan Intelektual, Raja Grafindo Persada, Jakarta, 2004, Hlm. 340 
diterima sebagai merek atau cap dagang, syarat mutlak dari padanya ialah bahwa merek ini harus mempunyai daya pembeda yang cukup 6 .

Pasal 1 angka 1 Undangundang Nomor 15 Tahun 2001 tentang Merek, disebutkan bahwa merek adalah tanda yang berupa gambar, nama, kata, huruf-huruf, angka-angka, susunan warna, atau kombinasi dari unsur-unsur tersebut yang memiliki daya pembeda dan digunakan dalam kegiatan perdagangan barang atau jasa, sedangkan dalam Pasal 1 Undangundang Nomor 20 Tahun 2016 tentang Merek dan Indikasi Geografis, dikatakan bahwa Merek adalah tanda yang dapat ditampilkan secara grafis berupa gambar, logo, nama, kata, huruf, angka, susunan warna, dalam bentuk 2 (dua) dimensi dan/atau 3 (tiga) dimensi, suara, hologram, atau kombinasi dari 2 (dua) atau lebih unsur tersebut untuk membedakan barang dan/atau jasa yang diproduksi oleh orang atau badan hukum dalam

\footnotetext{
${ }^{6}$ Sudargo Gautama, Hukum Merek Indonesia,
} Citra Aditya Bakti, Bandung, 1993, Hlm. 39 kegiatan perdagangan barang dan/atau jasa.. Hak merek dinyatakan sebagai hak eksklusif karena hak tersebut merupakan hak yang sangat pribadi bagi pemiliknya dan diberi hak untuk menggunakan sendiri atau memberi izin kepada orang lain untuk menggunakan sebagaimana ia sendiri menggunakannya ${ }^{7}$. Hak adalah sebagai kekuasaan yang diberikan oleh hukum kepada seseorang, dengan maksud untuk melindungi kepentingan orang tersebut ${ }^{8}$.

Dalam sistem hukum merek, untuk diakui sebagai merek dan dilindungi di bawah rezim hukum merek, harus terlebih dahulu ditempuh proses pendaftaran merek dan uji substansif ${ }^{9}$. Di samping itu harus ditempuh mekanisme pengumuman dalam waktu tertentu yang memungkinkan pihak-pihak yang dirugikan mengajukan bantahan

\footnotetext{
${ }^{7}$ Ahmadi Miru, Hukum Merek Cara Mudah Mempelajari Undang - undang Merek, Raja Grafindo Persada, Jakarta, 2005, Hlm. 12

${ }^{8}$ Satjipto Rahardjo, Ilmu Hukum, Alumni, Bandung, 1982, Hlm. 94

9 Ahmad M Ramli, Cyber Law dan HKI Dalam Sistem Hukum Indonesia, Refika Aditama, Bandung, 2004, Hlm. 10
} 
terhadap pendaftarn merek tersebut ${ }^{10}$. Hal ini dimaksudkan agar pihak yang dirugikan dapat mencegah pendaftaran merek yang dilakukan orang yang tidak beritikad baik. Merek diakui keberadaannya berdasarkan stelsel konstitutif, dengan kata lain, tidak ada perlindungan tanpa pendaftaran.

Pengaturan pendaftaran merek, dikenal sistem deklaratif dan sistem konstitutif. Sistem deklaratif menentukan bahwa si pemakai pertama yang berhak atas merek, sedangkan dalam sistem konstitutif (atributif) yang mendaftarkan pertamalah yang berhak atas merek dan dialah yang secara eksklusif dapat memakai merek tersebut. Artinya, hak eksklusif atas sesuatu merek diberikan karena adanya pendaftaran (required by registration $)^{11}$. Pendaftaran Merek sangat penting, mengingat hak atas merek sebagai hak eksklusif bagi pemilik merek timbul dari adanya

${ }_{11}^{10}$ Ibid, Hlm. 11

11 Muhamad Djumhana, Perkembangan Doktrin dan Teori Perlindungan Hak Kekayaan Intelektual, Citra Aditya Bakti, bandung, 2006, Hlm. 74 pendaftaran ${ }^{12}$. Jadi pemegang merek baru akan diakui atas kepemilikan mereknya kalau merek itu dilakukan pendaftaran. Hal ini sesuai dengan prinsip yang dianut dalam undangundang merek Indonesia, yaitu first to file principle, maka seseorang yang ingin memiliki hak atas merek, dia harus melakukan pendaftaran atas merek yang bersangkutan ${ }^{13}$.

Suatu merek yang telah didaftarkan dan memenuhi persyaratan substantif dan administratif, maka kepada pihak yang mengajukan permohonan merek akan mendapatkan sertifikat merek sebagai bukti hak atas merek. Hak atas merek sendiri diartikan sebagai hak eksklusif yang diberikan oleh Negara kepada pemilik merek yang terdaftar dalam daftar umum merek untuk jangka waktu tertentu dengan menggunakan sendiri merek tersebut atau memberikan izin kepada pihak lain untuk

\footnotetext{
12 Yusran Isnaini, Buku Pintar HAKI, Ghalia Indonesia, Bogor, 2010, Hlm. 34

13 Abdulkadir Muhammad, Kajian Hukum Ekonomi Hak Kekayaan Intelektual, Citra Aditya Bakti, Bandung, 2001, Hlm. 120
} 
menggunakannya ${ }^{14}$. Merek terdaftar mendapat perlindungan hukum untuk jangka waktu 10 (sepuluh) tahun sejak tanggal penerimaan dan jangka waktu perlindungan itu dapat diperpanjang (Pasal 28 UU No. 15 Tahun 2001 tentang Merek), sekarang diatur dalam Pasal 35 Undang-undang Nomor 20 Taun 2016 tentang Merek dan Indikasi Geografis).

Secara umum, merek tidak dapat didaftar atas dasar permohonan yang diajukan oleh pemohon yang beritikad tidak baik. Pemohon yang beritikad baik adalah pemohon yang mendaftarkan mereknya secara layak dan jujur tanpa ada niat apapun untuk membonceng, meniru, atau menjiplak ketenaran merek pihak lain demi kepentingan usahanya yang berakibat kerugian pada pihak lain itu atau menimbulkan kondisi persaingan curang, mengecoh, atau menyesatkan konsumen ${ }^{15}$.

14 Budi Agus Riswandi, M Syamsudin, Hak Kekayaan Intelektual dan Budaya Hukum, Raja Grafindo Persada, Jakarta, 2005, Hlm. 86

15 Ahmadi Miru, Op. Cit, Hlm. 13
Hak merek itu diberikan pengakuannya oleh Negara, pendaftaran atas merek merupakan suatu keharusan apabila seseorang menghendaki agar menurut hukum dipandang sah sebagai orang yang berhak atas merek. Bagi orang yang mendaftarkan mereknya terdapat suatu kepastian hukum bahwa dialah yang berhak atas merek itu ${ }^{16}$.

Namun demikian dalam praktik, ternyata merek yang sudah didaftarkan, masih dapat dilakukan gugatan oleh pihak lain, dan apabila dikabulkan gugatan tersebut, merek yang sudah terdaftar dapat dibatalkan atau dicabut dari kantor pendaftaran merek pada Dirjen Hak Kekayaan Intelektual (Berdasarkan Peraturan Presiden No. 44 Tahun 2015, tanggal 22 April 2015 tentang Kementerian Hukum dan HAM, maka Direktorat Jenderal Hak Kekayaan Intelektual diganti menjadi Direktorat Jenderal (Ditjen) Kekayaan Intelektual). Dengan demikian, sistem pendaftaran

16 Muhamad Djumhana dan R. Djubaedillah, Hak milik Intelektual (Sejarah, Teori, dan Prakteknya di Indonesia), Citra Aditya Bakti, Bandung, 1993, Hlm. 128 
konstitutif yang diharapkan melahirkan kepastian hukum, ternyata praktiknya belum sepenuhnya dapat dirasakan oleh para pendaftar merek. Menurut Sudikno Mertokusumo, kepastian hukum adalah jaminan bahwa hukum dijalankan, bahwa yang berhak menurut hukum dapat memperoleh haknya dan bahwa putusan dapat dilaksanakan 17. Walaupun kepastian hukum erat kaitannya dengan keadilan, namun hukum tidak identik dengan keadilan. Hukum bersifat umum, mengikat setiap orang, bersifat menyamaratakan, sedangkan keadilan bersifat subyektif, individualistis, dan tidak menyamaratakan.

Berdasarkan hal tersebut, ternyata merek yang sudah didaftarkan, masih dimungkinkan untuk dibatalkan melalui gugatan pembatalan merek, sehingga belum ada kepastian hukum bagi pendaftar merek, maka menarik untuk diteliti

17 Sudikno Mertokusumo, Mengenal Hukum Suatu Pengantar, Liberty, Yogyakarta, 1991, HIm. 134 mengenai Pembatalan Merek Terdaftar Dihubungkan Dengan Asas Kepastian Hukum Bagi Pemegang Merek.

2. Identifikasi Masalah

Dari uraian latar belakang masalah di atas, maka ada beberapa masalah yang dapat diidentifikasikan sebagai berikut :

1. Bagaimana pengaturan pembatalan merek terdaftar dalam sistem pendaftaran konstitutif ?

2. Sejauhmana implementasi pembatalan merek terdaftar dalam sistem pendaftaran konstitutif dihubungkan dengan asas kepastian hukum ?

3. Tujuan Penelitian

Adapun tujuan penelitian ini adalah :

1. Untuk memahami pengaturan pembatalan merek terdaftar dalam sistem pendaftaran konstitutif.

2. Untuk menjelaskan implementasi pembatalan 
merek terdaftar dalam sistem pendaftaran konstitutif dihubungkan dengan asas kepastian hukum.

\section{B. PEMBAHASAN}

1. Pengaturan Pembatalan Merek Terdaftar Dalam Sistem Pendaftaran Konstitutif

Hak Merek merupakan salah satu bentuk perlindungan Hak Kekayaan Intelektual (HKI), dimana hak eksklusif akan diberikan kepada pemilik atas suatu merek untuk menggunakan mereknya tersebut dalam perdagangan barang atau jasa untuk mana ia terdaftar. Jika suatu merek terdaftar untuk jenis pakaian jadi, misalnya, maka hak eksklusif si pemilik merek adalah sebagai satusatunya orang yang berhak menggunakan merek tersebut sebagai merek pakaian jadi, tapi tidak untuk jenis barang atau jasa yang lain.

Prinsip dasar pertama yang harus dipahami adalah bahwa hak eksklusif atas merek di Indonesia yang diatur berdasarkan baik UU Nomor 15 tahun 2001 tentang Merek maupun
Undang-undang Nomor 20 Tahun 2016 tentang Merek dan Indikasi Geografis, hanya diberikan pada merek yang telah terdaftar di Direktorat Jenderal Kekayaan Intelektual, Kementerian Hukum dan Hak Asasi Manusia RI (DJKI). Pendaftaran merek tersebut menganut prinsip first to file, dimana hak akan diberikan kepada pendaftar pertama. Prinsip ini berlaku pula di hampir semua negara, terkecuali di beberapa negara dengan sistem hukum anglosaxon seperti Inggris dan Amerika Serikat, dimana selain first to file juga diakui perlindungan berdasarkan first to use atau pemakaian pertama kali.

Selain first to file, sistem perlindungan merek di dunia, termasuk Indonesia menganut pula prinsip teritorialitas, yaitu bahwa hak eksklusif merek hanya berlaku di wilayah negara dimana merek tersebut didaftar. Dengan demikian, perusahaan-perusahaan yang aktivitas bisnisnya berlangsung lintas negara mutlak perlu melakukan pendaftaran atas merek-mereknya di negara-negara 
dimana aktivitas bisnisnya tersebut berada ${ }^{18}$.

Merek adalah tanda yang dapat ditampilkan secara grafis berupa gambar, logo, nama, kata, huruf, angka, susunan warna, dalam bentuk 2 (dua) dimensi dan/atau 3 (tiga) dimensi, suara, hologram, atau kombinasi dari 2 (dua) atau lebih unsur tersebut untuk membedakan barang dan/atau jasa yang diproduksi oleh orang atau badan hukum dalam kegiatan perdagangan barang dan/atau jasa (Pasal 1 angka 1 UU No. 20 Tahun 2016 tentang Merek dan Indikasi Geografis).

Pemilik merek memiliki hak yang dinamakan hak atas merek. Hak atas merek adalah hak eksklusif yang diberikan oleh Negara kepada pemilik merek yang terdaftar dalam Daftar Umum Merek untuk jangka waktu tertentu dengan menggunakan sendiri merek tersebut atau memberikan izin kepada pihak lain untuk menggunakannya (Pasal 1 angka 5 UU No. 20 Tahun 2016 tentang Merek dan

${ }^{18} \mathrm{Ibid}$
Indikasi Geografis). Perlindungan hukum terhadap merek terdaftar diberikan untuk jangka waktu 10 (sepuluh) tahun sejak tanggal penerimaan permohonan yang telah memenuhi persyaratan administratif (Pasal 35 ayat (1) UU No. 20 Tahun 2016 tentang Merek dan Indikasi Geografis, yang mana jangka waktu tersebut dapat diperpanjang (Pasal 35 ayat (2) UU No. 20 Tahun 2016 tentang Merek dan Indikasi Geografis).

Hak eksklusif pemilik merek diatur dalam Article 16 Paragraph (1), (2), dan (3), Article 21 TRIPs serta Article 6 bis Paris Convention sebagai berikut :

Article 16 TRIPs :

(1) The owner of a registered shall have the exclusive right to preven all third not having the owner's consent from using in the course of trade identical or similar signs for goods or services which are identical or similar to those in respect of which the trademarks is registered where such use would result in a likehood of confusion shall be 
presumed. The right described aove shall ot prejudice any eisting ptior rights, nor shall they affect the possibility of members making right available on the basis of use (Terjemahan bebas : pemilik merek dagang terdaftar memiliki hak eksklusif untuk mencegah semua pihak ketiga yang tidak memiliki izin pemilik, untuk menggunakan dalam kegiatan perdagangan, tanda-tanda yang sama persis atau memiliki kemiripan untuk barang atau jasa yang sama atau mirip dengan barang atau jasa atas mana merek telah didaftarkan, di mana harus telah diprediksi sebelumnya bahwa penggunaan semacam itu dapat mengakibatkan kebingungan . Hak yang dijelaskan di atas tidak mengurangi hak yang sudah ada, dan tidak akan mempengaruhi

kemungkinan Negara anggota menyediakan perlindungan hak merek dagang atas dasar penggunaan).

(2) Article 6 bis of the Paris Convention (1967) shall apply, mutatis mutandis, to services. In determining whether a trademark is welknown, member shall take account of the knowledge of the trademark in the relevant sector of the public, including knowledge in the member concerned which has been obtained as a result of the promotion of the trademark (Terjemahan bebas : Article 6 bis Konvensi Paris (1967) berlaku mutatis mutandis untuk jasa. Dalam menentukan apakah merek itu terkenal, anggota harus mempertimbangkan pengetahuan (masyarakat) atas merek yang bersangkutan pada sektor terkait, termasuk pengetahuan dalam anggota yang bersangkutan yang telah diperoleh sebagai hasil promosi merek dagang)

(3) Article 6 bis of the Paris Convention (1967) shall apply mutatis mutandis, too goods or services which are not similar to those in respect of which a trademark is registerd, provided that use of that trademark in relation to those goods or services would indicate a connection between those goods or services and the owner of the registered trademark are likely to be damaged by such use 
(Terjemahan bebas : Article 6 bis Konvensi Paris (1967) berlaku mutatis mutandis untuk barang atau jasa yang tidak sama dengan barang atau jasa atas mana suatu merek dagang didaftarkan, asalkan penggunaa merek dagang yang berkaitan dengan barang atau jasa tersebut akan menunjukan hubungan antara barang atau jasa pemilik merek terdaftar dan dengan ketentuan bahwa kepentingan merek terdaftar dapat dirugikan dengan penggunaan tersebut).

Article 21 :

Members may determine condition on the licencing and assignment of trademarks, it being understood that the compulsory licensing of trademarks shall not be permitted and that owner of egistered trademark shall have he right to assign the trademark with or withoutthe transfer of the business to which the trademark belongs (Terjemahan bebas : Negara anggota (perjanjian TRIPs) dapat menetapkan persyaratan untuk lisensi dan pengalihan hak merek, dengan pengertian bahwa lisensi wajib merek tidak akan diizinkan dan bahwa pemilik merek terdaftar berhak untuk menetapkan merek, dengan atau tanpa pengalihan bisnis, untuk yang merek milik mereka).

Article 6 bis Paris Convention

(1) The countries of the Union undertake, ex officio if their legislation so permits, or at the request of an interested party, to refuse or o cancel the registration, and to prohibit the use, of a trademark which constitutes a reproduction, an imitation, or a translation, liable to create confusion, of a mark considered by the competent authority of the country of registration or use to be well known in thet country as being already the marks of a person entitled to the benefits of Convention and used for identical or similargoods. These provision shall also apply when the essential part of the marks constitutes a reproduction of any such well known mark or an imitation liable to cerate confusion therewith (Terjemahan bebas : Negara anggota Konvensi Paris harus mengambil tindakan secara ex officio 
jika diizinkan oleh peraturan perundangundangannya atau atas dasar permintaan suatu pihak yang berkepentingan untuk menolak atau membatalkan pendaftaran dan untuk melarang penggunaan merek yang mengakibatkan suatu reproduksi, suatu tiruan atau suatu terjemahan yang menimbulkan kebingungan, suatu merek yang ditetapkan oleh pihak yang berwenang dari Negara di mana merek tersebut didaftarkan atau digunakan sebagai merek yang dikenal dalam Negara tersebut dan telah menjadi merek seseorang yang berhak untuk itu berdasarkan konvensi ini dan digunakan untuk produk yang identik atau produk yang mirip. Aturan ini juga berlaku manakala bagian esensial dari merek menimbulkan suatu reproduksi dari setiap merek yang dikenal atau suatu tiruan yang menyebabkan kebingungan.)

(2) A period of at least five years from the date of registration shall be allowed for requesting the cancellaion of such a mark. The countries of the
Union may provide for a period within which the prohibition of use must be requested (Terjemahan bebas : Suatu periode paling sedikit lima tahun sejak tanggal pendaftarannya harus dimungkinkan untuk pembatalan merek tersebut di atas. Negara anggota konvensi dapat menyediakan suatu periode di mana larangan penggunaan dapat dimintakan.

(3) No time limit shall be fixed for requesting the cancellation or the prohibition of the use of marks registered or used in bad faith (Terjemahan bebas : Tidak ada batas waktu yang ditetapkan untuk permintaan pembatalan atau larangan penggunaan dari merek terdaftar atau digunakan dengan itikad buruk).

Di Indonesia hak eksklusif diatur dalam Pasal 3 UU No. 15 Tahun 2001 tentang Merek, yang berbunyi : Pemilik merek terdaftar memiliki hak eksklusif untuk menggunakan mereknya dan memberikan izin bagi pihak lain untuk menggunakan mereknya. Dalam Undang-undang Nomor 20 Tahun 2016 tentang Merek 
dan Indikasi Geografis, diatur dalam Pasal 1 angka 5 yang berbunyi : Hak atas Merek adalah hak eksklusif yang diberikan oleh negara kepada pemilik Merek yang terdaftar untuk jangka waktu tertentu dengan menggunakan sendiri Merek tersebut atau memberikan izin kepada pihak lain untuk menggunakannya.

Manakala suatu merek telah disetujui untuk didaftar, maka pemilik merek terdaftar memiliki hak eksklusif untuk menggunakan merek terdaftar tersebut, termasuk : ${ }^{19}$

a. Hak untuk menggunakan merek terkait dengan produk barang dan/atau jasa dan menggunakan untuk bisnis yang relevan;

b. Hak eksklusif tersebut membuat pemilik merek terdaftar yang menikmati hak eksklusif, tidak ada satu pihak pun yang lain yang berhak untuk menggunakan merek yang

19 Rahmi Jened Hukum Merek Dalam Era global dan Integrasi Ekonomi, Prenada media Group, Jakarta, 2015, Hlm. 194 memiliki persamaan

secara keseluruhan

(identic) atau persamaan pada pokoknya (similar) untuk barang dan/atau jasa;

c. Hak untuk mengizinkan atau memberikan kewenangan bagi pihak lain untuk menggunakan merek terdaftarnya dengan cara menandatangani kontrak lisensi yang sesuai dengan hukum;

d. Kekuatan untuk menahan dan melarang pihak mana pun dari penggunaan merek yang memiliki persamaan secara keseluruhan (identic) atau persamaan pada pokoknya (similar) tanpa izin;

e. Hak untuk menjaminkan merek terdaftar dalam bisnis;

f. Hak untuk investasi, mengingat merek terdaftar merupakan aset tidak 
berwujud (intangible

asset) dan membuat investasi sesuai hukum yang berlaku;

g. Hak untuk mengalihkan merek terdaftar dengan atau tanpa bisnisnya;

h. Hak untuk mengalihkan pada ahli warisnya.

Dari setiap undang-undang yang mengatur merek, pada umumnya ditetapkan ketentuan yang mengatur mengenai sanksi-sanksi untuk pelanggar hak merek orang lain. Ketentuan yang mengaturnya dapat bersifat pidana, perdata ataupun adminisrasi, bahkan pula tindakan pencegahan lain yang bersifat non yuridis ${ }^{20}$. Pemegang merek yang mereknya digunakan oleh pihak lain dan mengakibatkan kerugian bagi pemilik merek tersebut, maka ia dapat mengajukan gugatan perdata ke pengadilan, dalam hal ini mengajukan gugatan ke Pengadilan Niaga.

\footnotetext{
${ }^{20}$ Budi Santoso, Pengantar Hak Kekayaan Intelektual, Pustaka Magister, Semarang, 2008, Hlm. 268.
}

Pembatalan merek dalam Undang-undang Nomor 20 Tahun 2016 tentang Merek dan Indikasi Geografis, diatur pada Pasal 76 sampai dengan Pasal 79. Pasal 76 ayat (1) berbunyi Gugatan pembatalan merek terdaftar dapat diajukan oleh pihak yang berkepentingan berdasarkan alasan sebagaimana dimaksud dalam Pasal 20 dan/atau Pasal 21, kemudian ayat (2) mengatakan Pemilik merek yang tidak terdaftar dapat mengajukan gugatan sebagaimana dimaksud pada ayat (1) setelah mengajukan permohonan kepada menteri, selanjutnya dalam ayat (3) mengatakan Gugatan pembatalan diajukan kepada Pengadilan Niaga terhadap pemilik merek terdaftar.

Pembatalan merek dalam Undang-undang Nomor 20 Tahun 2016 tentang Merek dan Indikasi Geografis, diatur pada Pasal 76 sampai dengan Pasal 79. Pasal 76 ayat (1) berbunyi Gugatan pembatalan merek terdaftar dapat diajukan oleh pihak yang berkepentingan berdasarkan alasan sebagaimana dimaksud dalam Pasal 20 dan/atau Pasal 21, kemudian 
ayat (2) mengatakan Pemilik merek yang tidak terdaftar dapat mengajukan gugatan sebagaimana dimaksud pada ayat (1) setelah mengajukan permohonan kepada menteri, selanjutnya dalam ayat (3) mengatakan Gugatan pembatalan diajukan kepada Pengadilan Niaga terhadap pemilik merek terdaftar.

Pasal 78 ayat (1) berbunyi Terhadap putusan Pengadilan Niaga atas gugatan pembatalan sebagaimana dimaksud dalam Pasal 76 ayat (3) dapat diajukan kasasi, selanjutnya dalam ayat (2), disebutkan bahwa Panitera pengadilan segera menyampaikan putusan kepada para pihak yang berengketa.

Pasal 79 mengatakan, Ketentuan mengenai alasan gugatan pembatalan sebagaimana dimaksud dalam Pasal 76 berlaku secara mutatis mutandis terhadap merek kolektif terdaftar.

Dari uraian di atas, maka dapat diketahui bahwa penggugat dapat mengajukan gugatan pembatalan merek berdasarkan alasan sebagai berikut :

1. Merek yang didaftarkan atas dasar permohonan yang diajukan oleh pemohon yang beritikad tidak baik;

2. Merek yang didaftarkan bertentangan dengan peraturan perundangundangan yang berlaku, moralitas agama, kesusilaan, atau ketertiban umum;

3. Merek tersebut telah menjadi milik umum;

4. Merek tersebut merupakan keterangan atau berkaitan dengan barang atau jasa yang dimohonkan pendaftarannya;

5. Merek tersebut mempunyai persamaan pada pokoknya atau keseluruhannya dengan merek milik pihak lain yang sudah terdaftar lebih 
dahulu untuk barang dan/atau jasa yang sejenis;

6. Merek

tersebut mempunyai persamaan pada pokoknya atau keseluruhannya dengan merek yang sudah terkenal milik pihak lain untuk barang dan/atau jasa sejenis;

7. Merek tersebut mempunyai persamaan pada pokoknya atau keseluruhannya dengan indikasi geografis yang sudah dikenal;

8. Merek tersebut merupakan atau menyerupai nama orang terkenal, foto, atau nama badan hukum yang dimiliki oleh orang lain, kecuali atas persetujuan tertulis dari yang berhak;

9. Merek tersebut merupakan tiruan atau menyerupai nama atau singkatan nama, bendera, lambang atau symbol atau emblem negara atau lembaga nasional maupun internasional, kecuali atas persetujuan tertulis dari pihak yang berwenang;

10. Merek tersebut merupakan tiruan atau menyerupai tanda atau cap atau stempel resmi yang digunakan oleh Negara atau lembaga pemerintah, kecuali atas persetujuan tertulis dari pihak yang berwenang.

\section{Implementasi pembatalan merek terdaftar dalam sistem pendaftaran konstitutif dihubungkan dengan asas kepastian hukum}

Merek dengan sistem
konstitutif, menentukan bahwa
pendaftaran merupakan keharusan agar
dapat memperoleh hak atas merek.
Tanpa pendaftaran, negara tidak akan
memberikan hak atas merek kepada
pemilik merek. Hal ini berarti tanpa
mendaftarkan merek, seseorang tidak
akan diberikan perlindungan hukum
oleh negara apabila mereknya ditiru


oleh orang lain. Pendaftaran merek yang digunakan di Indonesia sejak Undang-Undang Nomor 19 Tahun 1992 adalah sistem Konstitutif. Pada sistem Konstitutif ini perlindungan hukumnya didasarkan atas pendaftar pertama yang beritikad baik . Hal ini juga seperti yang tercantum dalam Pasal 4 Undang-undang Nomor 15 Tahun 2001 yang menyatakan bahwa merek tidak dapat didaftar oleh pemohon yang tidak beritikad baik, dalam Undang-undang Nomor 20 Tahun 2016 diatur dalam Pasal 21 ayat (3) yang berbunyi bahwa permohonan ditolak jika diajukan oleh Pemohon yang beriktikad tidak baik.

Dengan demikian menurut sistem konstitutif (aktif), bahwa yang berhak atas suatu merek adalah pihak yang telah mendaftarkan mereknya. Jadi pendaftaran merek itu menciptakan suatu hak atas merek tersebut, pihak yang mendaftarkan dialah satu-satunya yang berhak atas suatu merek dan pihak ketiga harus menghormati haknya pendaftar sebagai hak mutlak.
Sistem pendaftaran konstitutif apabila dihubungkan dengan kepastian hukum, yang didefiniskan oleh Jan Michiel Otto, kepastian hukum sebagai kemungkinan bahwa dalam situasi tertentu :

1. Tersedia aturan-aturan hukum yang jelas, konsisten dan mudah diperoleh (accessable), diterbitkan oleh atau diakui karena (kekuasaan) negara;

Aturan hukum mengenai sistem konstiutif sudah diatur dalam Undangundang No. 15 Tahun 2001 tentang Merek, yaitu terdapat dalam Pasal 3 yang berbunyi : " Hak atas merek adalah hak eksklusif yang diberikan oleh negara kepada pemilik merek yang terdaftar dalam Daftar Umum Merek untuk jangka waktu tertentu dengan menggunakan sendiri merek tersebut atau memberikan izin kepada 
pihak lain untuk menggunakannya".

Selanjutnya diatur juga dalam Pasal 3 Undangundang Nomor 20 Tahun 2016 Tentang Merek dan Indikasi Geografis, berbunyi :" Hak atas Merek diperoleh setelah Merek tersebut terdaftar". Ketentuan sistem konstitutif tersebut sudah cukup jelas, dan konsisten dilaksanakan dalam praktik, hal ini terbukti dengan banyaknya pendaftaran merek yang dilakukan oleh Pemohon Merek sebagaimana dapat dilihat pada Tabel 4 BAB III, serta ketentuan/aturan mengenai merek ini mudah diperoleh oleh masyarakat khususnya oleh setiap pemilik merek yang akan mendaftarkan mereknya di Direktorat Jenderal Kekayaan Intelektual. Undang- undang merek ini diterbitkan dan diakui oleh kekuasaan Negara (dalam hal ini oleh Dewan Perwakilan Rakyat dan Presiden).

2. Bahwa instansi-instansi pemerintah menerapkan aturan-aturan hukum itu secara konsisten dan juga tunduk dan taat terhadapnya;

Dalam hal ini, instansi yang terkait dengan proses pendaftaran merek adalah Direktorat Jenderal Kekayaan Intelektual khususnya Kantor Merek yang merupakan bagian dari Kementerian Hukum dan Hak Asasi Manusia. Kantor Merek ini sudah menjalankan/menerapkan ketentuan sebagaimana diatur dalam Pasal 3 dan ketentuan mengenai pendaftaran merek yang diatur oleh Undang-undang Merek tersebut, dan 
Kantor Merek telah menerima pendaftaran.

3. Bahwa pada prinsipnya bagian terbesar atau mayoritas dari warganegara menyetujui muatan isi dan karena itu menyesuaikan perilaku mereka terhadap aturanaturan tersebut;

Mengenai hal ini, dapat

diketahui bahwa setiap warga Negara khususnya pemilik merek yang menghendaki mereknya diakui dan dilindungi oleh Negara, mereka

mendaftarakan merek tersebut ke Direktorat Jenderal Kekayaan

Intelekual. Dengan fakta tersebut, dapat dipastikan bahwa warga Negara yang berkepentingan dengan pengakuan hak atas merek, mayoritas menyetujui muatan/isi undang-undang merek, khususnya yang menyangkut pendaftaran merek. Namun demikian

dalam praktik, masih banyak pendaftar merek yang mendaftarkan mereknya tidak dilakukan dengan itikad baik, hal mana terbukti dengan beberapa putusan pengadilan atau Mahkamah Agung yang membatalkan merek pendaftar dengan pertimbangan hukum bahwa merek pendaftar tersebut didaftarkan dengan itikad tidak baik.

4. Bahwa hakim-hakim (peradilan) yang mandiri dan tidak berpihak (independent and impartial judges) menerapkan aturan-aturan hukum tersebut secara konsisten sewaktu mereka menyelesaikan sengketa hukum yang dibawa kehadapan mereka;

Sengketa Hak Kekayaan Intelektual dapat 

Pengadilan Niaga, sebagaimana diatur dalam Pasal 76 ayat (2) UU no. 15 Tahun 2001 tentang Merek yang berbunyi : "Gugatan sebagaimana dimaksud pada ayat (1) diajukan kepada Pengadilan Niaga". Sedangkan dalam UU No. 20 Tahun 2016 tentang Merek dan Indikasi Geografis mengaturnya dalam Pasal 83 ayat (3) yang berbunyi : "Gugatan sebagaimana dimaksud dalam ayat (1) diajukan kepada Pengadilan Niaga". Banyak sengketa merek yang sudah diputus melalui Pengadian Niaga ini, majelis hakim dalam memberikan putusan tentang sengketa merek berdasarkan pada faktafakta hukum, dan pertimbangan hukum dalam putusan juga selalu berdasarkan ketentuan

dalam undang-undang merek dan ketentuan perundangan lain yang berkaitan dengan merek, yang dilakukan secara mandiri tanpa intervensi pihak lain dan tidak berpihak. Namun demikian dalam praktik, berkaitan dengan persepsi terhadap pengertian merek yang mempunyai persamaan pada pokoknya dari pendaftar merek terakhir dengan pendaftar merek terdahulu, terkadang di antara majelis hakim terdapat perbedaan pandangan mengenai hal itu. Contohnya, dalam perkara merek Aqua dengan Indoqua, dalam perkara ini, ternyata majelis hakim dalam tingkat kasasi (Putusan No. 017/K/N/HaKI/2003 tanggal 21 November 2003) dan peninjauan 
kembali (Putusan No. 04

PK/N/HaKI/2004, tanggal

4 November 2004),

menyatakan bahwa antara

merek Aqua dan Indoqua

tidak mempunyai

persamaan baik bentuk,

cara penempatan, cara

penulisan atau kombinasi

antara unsut ataupun bunyi

ucapannya. Putusan

tersebut bertentangan

dengan putusan Mahkamah

Agung sebelumnya,

berdasarkan putusan-

putusan Mahkamah Agung

Republik Indonesia No.

757 K/Pdt/1989, No. 980

K /Pdt/1990 dan No. 1371

K/Pdt/1993 yang telah

merupakan Yurisprudensi

tetap Mahkamah Agung,

telah memberikan

penilaian hukum terhadap

merek terkenal AQUA,

dan terhadap pemakaian

merek yang mengandung

kata AQUA atau QUA

dalam pendafataran merek
CLUB AQUA, AQUARIA

dan QUA-QUA

dikualifikasikan sebagai

beritikad tidak baik.

Begitupun perbedaan

persepsi antara majelis

hakim dengan petugas

pendaftaran merek,

contohnya bahwa suatu

merek yang didaftarkan

oleh pemohon merek, oleh

petugas kantor merek

setelah diperiksa baik

secara formal maupun

substantif dapat diterima

sebagai merek karena tidak

memiliki persamaan pada

pokoknya dengan

pendaftar merek terdahulu,

sehingga kepadanya

diberikan sertifikat merek,

tetapi belakangan ternyata

ada pihak lain yang

mengajukan gugatan

pembatalan merek, dan

oleh hakim dalam

putusannya dinyatakan

bahwa merek terdaftar

belakangan dinyatakan 
mempunyai persamaan pada pokoknya dengan merek terdaftar terdahulu.

5. Bahwa keputusan peradilan secara konkrit dilaksanakan.

Pengadilan Niaga yang telah memberikan putusan penyelesaian sengketa merek, dan putusan Kasasi oleh Mahkamah Agung, umumnya ditaati oleh para pihak yang bersengketa, begitupun atas putusan Pengadilan baik pada Pengadilan Niaga maupun Mahkamah Agung yang memerintahkan pencoretan pendafatarn merek tertentu, telah dilaksanakan oleh Direktorat Jenderal Kekayaan Intelektual.

Pembatalan merek terdaftar hanya dapat dilakukan oleh pihak yang berkepentingan atau pemilik merek, baik dalam bentuk permohonan kepada Direktorat Jenderal Kekayaan Intelektual maupun gugatan kepada Pengadilan Niaga dengan dasar alasan sebagaimana dimaksud dalam Pasal 4, Pasal 5, atau Pasal 6 Undang-undang Nomor. 15 Tahun 2001 tentang Merek, selanjutnya dalam Undang-undang No. 20 Tahun 2016 tentang Merek dan Indikasi Geografis diatur dalam Pasal 20 dan/atau Pasal 21. Adapun menurut Pasal 20 :

Merek tidak dapat didaftar jika:

a. bertentangan dengan ideologi negara, peraturan perundang-undangan, moralitas, agama, kesusilaan, atau ketertiban umum;

b. sama dengan, berkaitan dengan, atau hanya menyebut barang dan/atau jasa yang dimohonkan pendaftarannya;

c. memuat unsur yang dapat menyesatkan masyarakat tentang asal, kualitas, jenis, ukuran, macam, tujuan penggunaan barang dan/atau jasa yang dimohonkan pendaftarannya atau merupakan nama varietas 
tanaman yang dilindungi

untuk barang dan/atau jasa

yang sejenis;

d. memuat keterangan yang tidak sesuai dengan kualitas, manfaat, atau khasiat dari barang dan/atau jasa yang diproduksi;

e. tidak memiliki daya pembeda; dan/atau

f. merupakan nama umum dan/atau lambang milik umum.

Pasal 21 mengatakan :

(1) Permohonan ditolak jika Merek tersebut mempunyai persamaan pada pokoknya atau keseluruhannya dengan:

a. Merek terdaftar milik pihak lain atau dimohonkan lebih dahulu oleh pihak lain untuk barang dan/atau jasa sejenis;

b. Merek terkenal milik pihak lain untuk barang dan/atau jasa sejenis; c. Merek terkenal milik pihak lain untuk barang dan/atau jasa tidak sejenis yang memenuhi persyaratan tertentu; atau

d. Indikasi Geografis terdaftar.

(2) Permohonan ditolak jika Merek tersebut:

a. Merupakan atau menyerupai nama atau singkatan nama orang terkenal, foto, atau nama badan hukum yang dimiliki orang lain, kecuali atas persetujuan tertulis dari yang berhak;

b. Merupakan tiruan atau menyerupai nama atau singkatan nama, bendera, lambang atau simbol atau emblem suatu negara, atau lembaga nasional maupun internasional, kecuali atas persetujuan 
tertulis dari pihak yang berwenang;

c. merupakan tiruan atau menyerupai tanda atau cap atau stempel resmi yang digunakan oleh negara atau lembaga Pemerintah, kecuali atas persetujuan tertulis dari pihak yang berwenang.

(3) Permohonan ditolak jika diajukan oleh Pemohon yang beriktikad tidak baik.

(4) Ketentuan lebih lanjut mengenai penolakan Permohonan Merek sebagaimana dimaksud pada ayat (1) huruf a sampai dengan huruf c diatur dengan Peraturan Menteri.

Implementasi pembatalan merek terdaftar, dapat dilihat dari beberapa kasus yang ditangani oleh Pengadilan Niaga sampai tingkat Kasasi dan Peninjauan Kembali, seperti Kasus :
1. DAVID OFF, Rokok (kelas 34), Remmtsma Cigarettenfabriken (Jerman) vs N.V. Sumatra Tobacco Trading Company;

2. CESARE PACIOTTI, Busana dan Sepatu (kelas 25), Cespa SRL (Italia) vs Piong San Po;

3. BENETTON, Rokok (kelas 34), Benetton Group SPA (Italia) vs NV. Sumatra Tobacco Trading Company

4. JIANG DONG, Mesin Diesel (kelas 7), Jiangsu Jiangdong Group corp (RRC) vs. Musdjaja Trihadi.

5. UNITED, minyak pelumas (kelas 4), NV. Sumatra Tobacco Trading Company vs Direktorat Jenderal Hak Kekayaan Intelektual.

6. RDL, Kosmetik (kelas 3), RDL Pharmaceutical Laboratory, Inc (Filipina) vs PT. Sparindo Mustika.

7. AQUA vs INDOQUA, air mineral (kelas 32), PT. Aqua Golden Mississippi Tbk vs H.M. Mansyur Syaerozi

8. HOLLAND BAKERY vs BAKERY HOLAN, Restoran (kelas 
42), toko roti (kelas 30), dan kantong plastik (kelas 16), PT. Mustika Citrarasa vs Drs. F.X.Y. Kiatanto S

9. 100 vs GAGA 100, Mi instan (kelas 30), Drs Harry Sanusi vs PT. Jakarana Tama

10. TOP 1 vs MEGATOP, Oli (kelas 4), PT. Topindo Atlas Asia vs. PT. Lumassindo Perkasa.

11. CAP KELINCI vs RABID BRAND, Pasah kayu dan pisau serut (kelas 8), Sigit Soegianto (CV. Kurnia Abadi) vs.PT. Inax Internasional Corporation

12. INDOMIE, CHIKI dan Merek lainnya, Djajadi Djaja vs PT. Indofood Sukses Makmur, Anthony Salim, Ibrahim Risjad, Djuhar Sutarno, dan Sudwikatmono.

13. JORAN, mesin (kelas 7), American Tool Companies A/S (Denmark) vs Sunandy Linanda

Dari beberapa kasus tersebut, dapat diketahui bahwa beberapa merek yang sudah terdaftar, ternyata dapat dibatalkan, dengan alasan :

1. Merek terdaftar yang pendaftarannya dilakukan oleh pihak yang tidak beritikad baik (kasus

CESARE PACIOTTI, JIANG DONG, RDL, HOLLAND BAKERY);

2. Merek terdaftar yang mengandung adanya persamaan pada pokoknya atau keseluruhannya dengan merek pihak lain yang sudah terdaftar lebih dahulu untuk barang atau jasa sejenis yang termasuk dalam satu kelas (kasus BENETTON, CASARE PACIOTTI, JIANG DONG, PAUL \& SHARK YACHTING, JORAN, RDL, HOLLAND BAKERY, RABBIT BRAND);

3. Merek terdaftar yang mengandung adanya persamaan pada pokoknya atau keseluruhannya dengan merek yang sudah terkenal milik pihak lain untuk barang dan/atau jasa sejenis (BENETTON, 
JORAN, CESARE PACIOTTI).

Dengan demikian,

berdasarkan uraian di atas baik ditinjau dari sistem hukum maupun asas kepastian hukum, dan beberapa putusan Pengadilan, dan juga memperhatikan kelebihan dan kelemahan dari sistem konstitutif dan sistem deklaratif, maka penulis berpendapat bahwa sistem pendaftaran merek yang dapat melindungi pemilik merek terdaftar yang beritikad baik dalam Sistem Pendaftaran Merek di Indonesia adalah Sistem Konstitutif, dengan syarat bahwa pendaftar harus mendaftarkan mereknya dengan itikad baik, di samping itu merek yang didaftarkan tidak mengandung persamaan pada pokoknya atau keseluruhannya dengan merek yang sudah terdaftar lebih dahulu dan merek yang didaftar itu tidak mengandung persamaan pada pokoknya atau keseluruhannya dengan merek terkenal, selanjutnya merek yang sudah terdaftar tersebut harus sungguh sungguh digunakan. Di samping itu, bahwa sistem konstitutif ini sesuai dengan ketentuan TRIPs sebagaimana diatur dalam Pasal 6 ayat (1) TRIPs, yang merupakan lampiran WTO, di mana Indonesia sudah meratifikasi WTO Agreement melalui Undangundang Nomor 7 Tahun 1994. Kepastian hukum dan perlindungan hukum bagi pendaftar merek akan diberikan sepanjang pendaftaran itu dilakukan dengan itikad baik.

\section{B. PENUTUP}

Dari uraian tersebut di atas, dapat diberikan kesimpulan dan saran sebagai berikut :

\section{Kesimpulan :}

a. Pengaturan pembatalan merek terdaftar dalam sistem pendaftaran konstitutif khususnya di Indonesia, sudah diatur dalam Undang-undang Nomor 20 Tahun 2016 tentang Merek dan Indikasi Geografis, pada Pasal 76 sampai dengan Pasal 79.

b. Implementasi pembatalan merek terdaftar dalam sistem pendaftaran konstitutif sudah sesuai dengan asas kepastian hukum 
2. Saran :

a. Bagi pendaftar merek, sebaiknya sebelum mendaftarkan mereknya, maka perlu terlebih dahulu mengetahui bahwa merek tersebut belum pernah ada yang mendaftarkan sebelumnya, sehingga pendaftar merek tersebut dianggap telah melakukan pendaftaran dengan itikad baik.

b. Untuk adanya kepastian hukum bagi pendaftar merek, maka pendaftaran merek tersebut harus dilakukan dengan tidak melanggar ketentuan Pasal 20 dan 21 UU No. 20 Tahun 2016. Di samping itu, petugas pendaftaran merek di Direktorat Jenderal Kekayaan Intelektual, harus sungguh-sungguh mengetahui merek yang sudah terdaftar, dan paham atas persepsi mengenai persamaan pada pokoknya atas merek yang sudah terdaftar dengan merek yang akan didaftarkan.

\section{DAFTAR PUSTAKA}

Djumhana, Muhamad, dan R. Djubaedillah., 1993. Hak milik Intelektual (Sejarah, Teori, dan Prakteknya di Indonesia), Bandung: Bandung:Citra Aditya Bakti.

Djumhana, Muhamad., 2006. Perkembangan Doktrin dan Teori Perlindungan Hak Kekayaan Intelektual, Bandung: Citra Aditya Bakti.

Firmansyah,,Hery., 2011.

Perlindungan Hukum Terhadap Merek, Jakarta: Pustaka Yustisia.

Gautama, Sudargo., 1993. Hukum

Merek Indonesia, Bandung: Citra Aditya Bakti.

Isnaini,Yusran.,2010. Buku Pintar $H A K I$, Bogor: Ghalia Indonesia.

Jened, Rahmi., 2015. Hukum Merek Dalam Era global dan Integrasi Ekonomi, Jakarta:Prenada media Group.

Maryana, Gozali Abdillah, Cecep Samsu., 2013. Hak Kekayaan Intelektual Menurut Hukum Islam dan Hukum Adat, , Jurnal Scientica, vol I No. 2.

Mertokusumo, Sudikno., 1991. Mengenal Hukum Suatu 
Pengantar, Yogyakarta: Liberty.

Miru, Ahmadi., 2005. Hukum Merek Cara Mudah Mempelajari Undang - undang Merek, Jakarta: Raja Grafindo Persada.

Muhammad, Abdulkadir., 2001. Kajian Hukum Ekonomi Hak Kekayaan Intelektual, Bandung:Citra Aditya Bakti.

Rahardjo, Satjipto., 1982. Ilmu Hukum, Bandung: Alumni.

Ramli, Ahmad M., 2004. Cyber Law dan HKI Dalam Sistem Hukum Indonesia, Bandung:Refika Aditama.
Riswandi, Budi Agus, M Syamsudin., 2005. Hak Kekayaan Intelektual dan Budaya Hukum, Jakarta:Raja Grafindo Persada.

Santoso,Budi., 2008. Pengantar Hak Kekayaan Intelektual, Semarang:Pustaka Magister.

Tim Lindsey, Eddy Damian, Simon Butt, Tomi Suryo Utomo, 2003., Hak Kekayaan Intelektual SuatuPengantar, Bandung: Alumni.

Utomo, Tomi Suryo., 2010. Hak kekayaan intelektual (HKI) di Era Global Sebuah Kajian Kontemporer, Yogyakarta : Graha Ilmu. 